\title{
correspondence
}

\section{The scientific civil service}

SIR,--Your leading article of November 18, "Don't Move", is itself guilty of throwing "the same old accusations" at the scientific civil service without any supporting evidence. The IPCS would certainly agree that the scientific civil service still lacks the right openings for mature scientists whether from within or without. It cannot, however, accept that the scientific civil servant is considerably better paid than his counterpart elsewhere; nor do scientists in the civil service feel particularly secure in their jobs at a time when cuts in public expenditure are raising real threats of redundancy.

It is of course true that industrialists frequently complain that they find it difficult to recruit in competition with the service; they are less willing to make public the details of the terms they themselves offer to scientists so that comparisons can be fairly made. Meanwhile the trend away from science continues in both the schools and the universities. The recent report from the Select Committee on Science and Technology, "University-Industry Relations", underlines the importance of reversing that trend. It will not be done by continued sniping at particular employment sectors but by improving the status of engineers and scientists in the community at large and, as the Select Committee recognises, by giving them "the opportunity of moving into the top echelons of management with as much ease as their counterparts in Germany, France or the USA and as their counterparts in Great Britain who have chosen to study law or accountancy".

Greater movement of scientists between different sectors of employment, though desirable, will not of itself solve the underlying problem of the un- attractiveness of science as a careerwhether in industry or the civil service.

\section{Margaret Platt}

Assistant General Secretary,

Institution of Professional

Civil Servants,

London WC2, UK

\section{International contacts}

SIR,-I would like to complete Professor Burhop's article ("A case of suitable treatment?", November 11) by one relevant remark. At the same time as London created obstacles in issuing British entry visas for some delegates of the World Federation of Scientific Workers' General Assembly, the former vicc-president of the Federation and a long term head of its Prague Regional Secretariat, Academican Ivan Málek, was visited by two gentlemen from the Prague police, who confiscated his foreign passport, valid only for East European countries-perhaps from fears that he might try to participate in the Pugwash meeting in August in East Germany, or the London Assembly.

I fully understand Professor Burhop's indignation about the bureaucratic obstacles to realising international scientific contacts. What I don't understand is why he does not publicly condemn equally strongly the incomparably heavier fact that thousands and thousands of scientists from the USSR and Eastern European countries are extremely restricted in travelling abroad, that every single journey must be approved and depends fully on the goodwill of the authorities and political views of each applicant?

Professor Málek, a scientist with an international reputation and a member of many international organisations, committees and boards, has not been allowed to leave Czechoslovakia for over 6 years (although he is constantly being invited abroad), and only because of his disapproval of occupation of Czechoslovakia in 1968 by Soviet and "allied" armies.

FRANTIŠEX $\mathbf{J}_{\text {ANOUCH }}$

Stockholm,

Sweden

\section{USSR river diversions}

SIR,-There is a disturbing aspect of the Soviet plan to divert the rivers Irtysh and $\mathrm{Ob}$ southward (December 2, page 390) which your correspondent does not mention. Calculations reported by Aagaard and Coachman in Eos (56, 485 ) suggest that by removing or reducing the low salinity layer at the surface of part of the Arctic Ocean such a scheme could allow deeper convection of the surface waters, encouraging ice to melt with perhaps a positive feedback as the albedo of the region is thereby reduced. Likely results, they suggest, "would be (1) prolonged icefree conditions because of deepreaching free convection.... (2) the release of large amounts of heat from warm Atlantic water during the cold months, and (3) the elevation of quite saline water into close proximity with the sea surface".

It is not clear, of course, whether such effects should be regarded as desirable or undesirable; in the present state of the art regarding our understanding of climatic changes we can only say that repercussions of one kind or another on the general atmospheric circulation would be inevitable. Given the uncertainties involved, however, it seems most unwise to carry out the experiment.

JOHN GRIBBIN

Science Policy Research Unit.

University of Sussex,

Brighton, UK

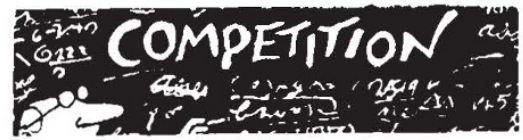

\section{Competition 11}

Readers are invited to submit descriptions, in epigrammatic reportorial form, of the demeanour, condition or action of any of the famous scientists (past or present) participating in an imaginary general symposium. Submissions should offer some humorous association with the scientists' work, for example, "Faraday was incapacitated", "Boyle and Charles felt the meeting was ' $a$ perfect gas'". Closing date for entries: February 16. (Competition inspired by Charles S. Cope of Parkersburg, West Virginia.)

Competition 10. "Prehistoric camels often sit down carefully. Perhaps their joints creak. Early oiling might provide permanent relief". These memorable phrases earn Dr P. Little, of Wantage, UK, $£ 10$ as the best mnemonic of a rather disappointing bunch. They remind us that the geological epochs are Precambrian, Cambrian, Ordovician, Silurian, Devonian, Carboniferous, Permian, Triassic, Jurassic, Cretaceous, Eocene, Oligocene, Miocene, Pliocene, Pleistocene and Recent (with apologies to the Paleocene).

As we said to our accounts department, "Prepare cheque of suitable denomination. Competitor pleases the judges, conquering easily over many people's poorer reminders". 